\title{
Highly Efficient RNA-Synthesizing System That Uses Isolated Human Mitochondria: New Initiation Events and In Vivo-Like Processing Patterns
}

\author{
GEORGE GAINES AND GIUSEPPE ATTARDI* \\ Division of Biology, California Institute of Technology, Pasadena, California 91125
}

Received 21 March 1984/Accepted 14 May 1984

\begin{abstract}
A highly efficient RNA-synthesizing system with isolated HeLa cell mitochondria has been developed and characterized regarding its requirements and its products. In this system, transcription is initiated and the transcripts are processed in a way which closely reproduces the in vivo patterns. Total RNA labeling in isolated mitochondria proceeds at a constant rate for about $30 \mathrm{~min}$ at $37^{\circ} \mathrm{C}$; the estimated rate of synthesis is at least 10 to $15 \%$ of the in vivo rate. Polyadenylation of the mRNAs is less extensive in this system than in vivo. Furthermore, compared with the in vivo situation, rRNA synthesis in vitro is less efficient than mRNA synthesis. This is apparently due to a decreased rate of transcription initiation at the rRNA promoter and probably a tendency also for premature termination of the nascent rRNA chains. The 5'-end processing of rRNA also appears to be slowed down, and it is very sensitive to the incubation conditions, in contrast to mRNA processing. It is suggested that the lower efficiency and the lability of rRNA synthesis and processing in isolated mitochondria may be due to cessation of import from the cytoplasm of ribosomal proteins that play a crucial role in these processes. The formation of the light-strand-coded RNA 18 (7S RNA) is affected by high pH or high ATP concentration differently from the overall light-strand transcription. The dissociation of the two processes may have important implications for the mechanism of formation and the functional role of this unusual RNA species. The high efficiency, initiation capacity, and processing fidelity of the in vitro RNAsynthesizing system described here make it a valuable tool for the analysis of the role of nucleocytoplasmicmitochondrial interactions in organelle gene expression.
\end{abstract}

Recent work from this laboratory has shown that the heavy $(\mathrm{H})$ strand of HeLa cell mitochondrial DNA (mtDNA) is the site of two overlapping transcription events $(4 \mathrm{a}, 12,19$. 20). A considerable amount of evidence suggests that one of these events is responsible for the synthesis of the bulk of rRNA, whereas the other results in the synthesis of a polycistronic molecule which corresponds to almost the entire $\mathrm{H}$ strand and is destined to be processed to yield the mRNAs and most of the tRNAs encoded in the $\mathrm{H}$ strand (Fig. 1). The initiation of the two $\mathrm{H}$-strand transcription events and that of light (L)-strand transcription occur in close proximity to each other in the region of mtDNA upstream of the origin of H-strand synthesis (10). This clustering of the three putative promoters may underlie the integrated control of expression of the corresponding transcription units, whereas their proximity to the origin of $\mathrm{H}$ strand synthesis may reflect the existence of a link between transcription events and mtDNA replication. To investigate further, under conditions allowing easy experimental manipulations, the molecular mechanisms, controls, and interrelationships of the mtDNA transcription and RNA processing events which occur in HeLa cell mitochondria, we developed a system for studying RNA synthesis in isolated organelles. In this system, mtDNA transcription and RNA processing proceed in a way closely resembling, qualitatively and quantitatively, the in vivo processes. By appropriately varying the conditions of incubation, we have been able to affect differentially various DNA transcription and RNA processing phenomena occurring in mitochondria and thus to obtain information concerning the mechanisms involved and the interrelationship between the individual events.

\footnotetext{
* Corresponding author.
}

\section{MATERIALS AND METHODS}

Cell growth and mitochondria isolation. HeLa cells were grown in suspension in modified Eagle medium supplemented with $5 \%$ calf serum, with a continuous flow of $5 \% \mathrm{CO}_{2}$ in air being flushed over the medium to keep the $\mathrm{pH}$ constant (15). Exponentially growing cells were harvested, washed two times with $1 \mathrm{mM}$ Tris-hydrochloride $\left(\mathrm{pH} \mathrm{7.0)}\left(25^{\circ} \mathrm{C}\right)\right.$ $0.13 \mathrm{M} \mathrm{NaCl}-5 \mathrm{mM} \mathrm{KCl}-7.5 \mathrm{mM} \mathrm{MgCl}_{2}$, and broken in onehalf of the packed cell volume of $3.5 \mathrm{mM}$ Tris-hydrochloride (pH 7.8)-2 mM NaCl-0.5 mM MgCl 2 by using a Thomas homogenizer with a motor-driven Teflon pestle. The homogenate was immediately mixed with $1 / 9$ of the cell volume of $0.35 \mathrm{M}$ Tris-hydrochloride ( $\mathrm{pH} 7.8)-0.2 \mathrm{M} \mathrm{NaCl}-50 \mathrm{mM}$ $\mathrm{MgCl}_{2}$ and spun for $3 \mathrm{~min}$ at $900 \times g$ to pellet unbroken cells and nuclei. The supernatant was recentrifuged under the same conditions. The final supernatant was portioned into Eppendorf tubes and spun at full speed $(12,700 \times g)$ for $1 \mathrm{~min}$ in an Eppendorf microfuge. The mitochondrial pellets were washed one time with the appropriate incubation buffer and pelleted. All manipulations up to this point were carried out at $4^{\circ} \mathrm{C}$.

In vitro labeling and isolation of mitochondrial nucleic acids. Samples of the mitochondrial fraction, each derived from $\sim 0.5 \mathrm{~g}$ of $\mathrm{HeLa}$ cells $(\sim 0.7 \mathrm{mg}$ of mitochondrial protein), were resuspended in $0.5 \mathrm{ml}$ of the appropriate incubation buffer in Eppendorf tubes. The standard medium contained $10 \%$ glycerol, $35 \mathrm{mM}$ Tris-hydrochloride $(\mathrm{pH} 7.8)$, $20 \mathrm{mM} \mathrm{NaCl}, 5 \mathrm{mM} \mathrm{MgCl}, 1 \mathrm{mM}$ ATP, $1 \mathrm{mg}$ of bovine serum albumin (BSA) per $\mathrm{ml}$, and 5 to $50 \mu \mathrm{Ci}$ of $\left[\alpha{ }^{32} \mathrm{P}\right] \mathrm{UTP}$ (400 to $600 \mathrm{Ci} / \mathrm{mmol}$ ). Unless otherwise specified, incubation was at $37^{\circ} \mathrm{C}$ for $30 \mathrm{~min}$. This system differs from the RNAsynthesizing system with isolated HeLa cell mitochondria previously developed in this laboratory (C. E. Novitski, Ph.D. thesis, California Institute of Technology, Pasadena, 

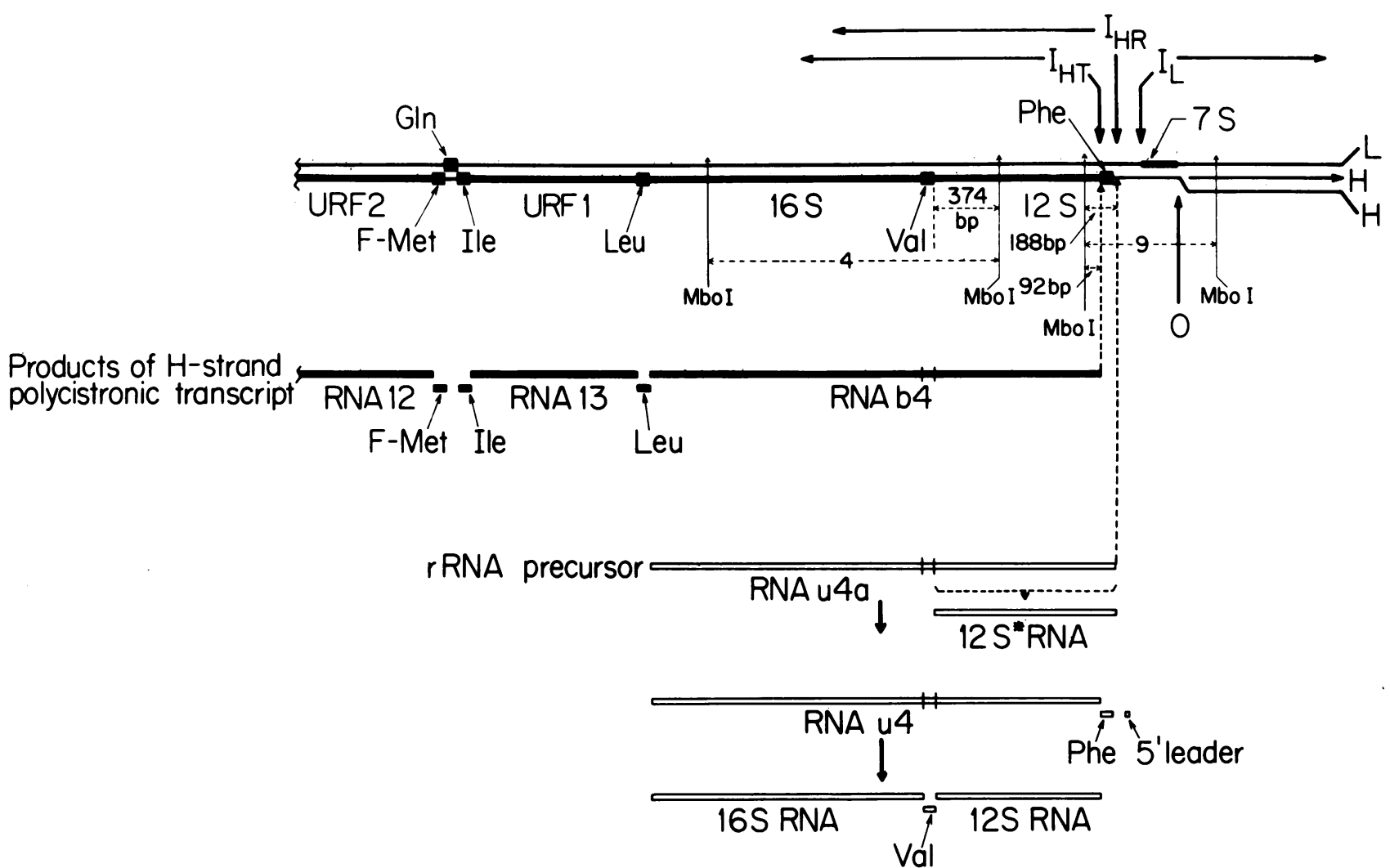

FIG. 1. Portion of the HeLa cell mtDNA genetic and transcription maps illustrating the rRNA gene region and the adjacent regions (2, 9, $24,26)$. The downward arrows in the upper portion of the diagrams indicate the initiation sites for $H$-strand $\left(I_{H T}\right.$ and $\left.I_{H R}\right)$ and $L$-strand transcription $\left(\mathrm{I}_{\mathrm{L}}\right)(19)$, and the upward arrow indicates the position of the origin of H-strand synthesis $(0)(10)$. The leftward and rightward arrows indicate the direction of $\mathrm{H}$ - and L-strand transcription, respectively. In the lower portion of the diagram, the precise mapping positions of the rDNA transcripts and mRNAs identified in previous work $(12,20,26)$ are shown. The Mbol fragments utilized in the S1 mapping experiments are also shown.

1979 ) in the lower concentrations of monovalent cation and $\mathrm{Mg}^{2+}$, the higher $\mathrm{pH}$, and the higher temperature of incubation.

After the incubation, the mitochondrial samples were pelleted at $12,700 \times g$ for 1 min and washed two times with $10 \%$ glycerol-10 mM Tris-hydrochloride (pH 6.8)-0.15 mM $\mathrm{MgCl}_{2}$ at $4^{\circ} \mathrm{C}$. The pellets were suspended in $1 \mathrm{ml}$ of $10 \%$ glycerol-10 mM Tris-hydrochloride ( $\mathrm{pH} \mathrm{8.0)-1} \mathrm{mM} \mathrm{CaCl}$, incubated with $200 \mathrm{U}$ of micrococcal nuclease each at room temperature for $\mathbf{2 0} \mathrm{min}$, and then washed two times with $10 \%$ glycerol-10 mM Tris-hydrochloride ( $\mathrm{pH} 7.5$ )-1 mM EDTA at $4^{\circ} \mathrm{C}$. The mitochondrial samples were then lysed with $0.35 \mathrm{ml}$ of $0.5 \%$ sodium dodecyl sulfate-10 mM Tris-hydrochloride (pH 7.4)-0.15 M NaCl-1 mM EDTA (sodium dodecyl sulfate buffer) and incubated with $100 \mu \mathrm{g}$ of pronase for $15 \mathrm{~min}$ at $30^{\circ} \mathrm{C}$. Phenol extraction, fractionation by oligodeoxythymidylate [oligo(dT)]-cellulose chromatography, and electrophoretic analysis in $\mathrm{CH}_{3} \mathrm{HgOH}$-agarose gels of the mitochondrial nucleic acids were carried out as previously described $(21,24,26)$. A portion of each extracted nucleic acid sample was acid precipitated $(1 \mathrm{~N} \mathrm{HCl}, 50 \mathrm{mM}$ sodium pyrophosphate) and collected on a GF/C membrane for determination of total incorporated radioactivity. Quantitation of the autoradiograms of the $\mathrm{CH}_{3} \mathrm{HgOH}$-agarose gels was carried out by using a Joyce-Loebl double-beam densitometer and analyzing the peaks with a digitizer.

S1 protection analysis. Hybridization of in vitro-labeled
RNA species with M13-cloned single-stranded $M b o$ I fragment 4 or 9 of human mtDNA (M. King, unpublished data) was carried out under high-formamide conditions favoring RNA-DNA hybridization over DNA-DNA reassociation (8). Briefly, samples of labeled RNA were mixed with the appropriate unlabeled M13-cloned DNA fragment, lyophilized, resuspended in $20 \mu \mathrm{l}$ of $80 \%$ formamide-20 mM PIPES [piperazine- $N, N^{\prime}$-bis(2-ethanesulfonic acid)] buffer $(\mathrm{pH}$ 6.4)-0.375 M NaCl-0.5 mM EDTA, heated to $68^{\circ} \mathrm{C}$ for 10 min, and incubated at $49^{\circ} \mathrm{C}$ for 6 to $8 \mathrm{~h}$. S1 digestion buffer $(0.25 \mathrm{M} \mathrm{NaCl}, 40 \mathrm{mM}$ sodium acetate [pH 4.5$], 3 \mathrm{mM} \mathrm{ZnCl}$, $10 \mu \mathrm{g}$ of denatured salmon sperm DNA per $\mathrm{ml}$ ) was added to $200 \mu \mathrm{l}$, and the samples were then digested with $165 \mathrm{U}$ of S1 nuclease (Sigma Chemical Co.) at $41^{\circ} \mathrm{C}$ for $30 \mathrm{~min}$. The reaction was stopped by addition of $200 \mu$ l of sodium dodecyl sulfate buffer, followed by two ethanol precipitations. The S1-resistant products were analyzed by electrophoresis through an $8 \%$ polyacrylamide- $8 \mathrm{M}$ urea gel, followed by autoradiography. To quantitate the radioactivity associated with the S1-resistant fragments, appropriate bands were cut from the dried gels and counted in a scintillation counter by using a toluene-based scintillation fluid. Similarly sized slices cut immediately above and below the bands in question were subjected to the same analysis to provide an estimate of the background radioactivity.

Strand homology analysis of in vitro mtDNA transcripts. In 
vitro-labeled RNA and separated strands of total mtDNA were hybridized, and the hybrids were analyzed as previously described (7).

\section{RESULTS}

Electrophoretic patterns of RNA labeled in isolated mitochondria. The oligo(dT)-cellulose-bound and unbound fractions of the in vitro-synthesized mitochondrial RNA exhibited electrophoretic patterns in $\mathrm{CH}_{3} \mathrm{HgOH}$-agarose slab gels similar to those observed for the in vivo-synthesized RNA (Fig. 2). Almost all the in vivo-synthesized oligo(dT)-cellulose-bound RNA species previously identified (1, 20) (Fig. 2, lane 3) are recognizable in the pattern of the in vitrosynthesized oligo(dT)-cellulose-bound RNA (lane 2). (The three large L-strand-coded RNA species 1, 2, and 3 were visible in some experiments after very long exposure of the autoradiogram.) The major oligo(dT)-cellulose-unbound RNA species produced in vivo, i.e., the large (16S) and small (12S) rRNA and the tRNAs (lane 4), are also present in the in vitro pattern (lane 1). Hence, mtDNA is transcribed and RNA is processed in isolated mitochondria in a way qualitatively similar to that for intact cells. However, there are some quantitative differences between the mtDNA transcription and RNA processing events in the two experimental situations, as discussed below.

Compared with the in vivo pattern, the most important difference is that the rate of rRNA synthesis in isolated organelles is considerably reduced relative to the rate of mRNA synthesis. This decrease is especially pronounced for 16S RNA. From densitometric measurements it was estimated that the labeling of the small rRNA is only 2 to 10 times that of the individual mRNA species (for example, mRNAs $9,14,15$, and 16), instead of 20 to 40 times, as it is in vivo (4). Furthermore, the observed ratio of labeling of the large to the small rRNA species is, under optimal conditions, 0.1 to 0.5 in different experiments, compared with $\sim 1.6$, which is expected for equimolar amounts of the labeled species. The RNA species designated as $12 S^{*}$ in the pattern of in vitrosynthesized RNA, which comigrates with mRNA 12 on $\mathrm{CH}_{3} \mathrm{HgOH}$-agarose gels (Fig. 2, lane 1), has been identified as a precursor of $12 \mathrm{~S}$ rRNA, carrying at its $5^{\prime}$ end the tRNA $^{\text {Phe }}$ sequence and the $5^{\prime}$ leader (12), indicating that the $5^{\prime}$-end processing of the rRNAs is somewhat slowed under these conditions.

Polyadenylation of the mRNAs appears to be less efficient in isolated organelles. Under the standard incubation conditions specified above, the proportion of the total in vitrolabeled RNA which was retained on oligo(dT)-cellulose varied considerably in different experiments (between 1 and $10 \%$ ) for unknown reasons. Although the highest proportion of oligo(dT)-cellulose-bound RNA observed in the present work ( $\sim 10 \%$; Fig. 2$)$ is within the range of retention values observed for mitochondrial RNA labeled in vivo during a 15min $\left[5-{ }^{3} \mathrm{H}\right]$ uridine pulse (10 to $15 \%$; A. Chomyn, unpublished data), this is mainly due to the much lower efficiency of rRNA synthesis in isolated mitochondria, which results in a marked decrease in the amount of oligo(dT)-celluloseunbound RNA. The mRNAs synthesized in vitro are indeed less extensively polyadenylated than the in vivo-synthesized species. In fact, the large majority of every mRNA labeled in isolated organelles $(>80 \%)$ did not bind to oligo(dT) cellulose (Fig. 2), whereas the bulk of the individual in vivosynthesized mRNAs bound. As a result, oligo(dT)-cellulose chromatography of in vitro-labeled RNA (Fig. 2, lanes 1 and 2) did not allow the near-complete separation of rRNA and mRNA species that is obtained with in vivo-labeled material

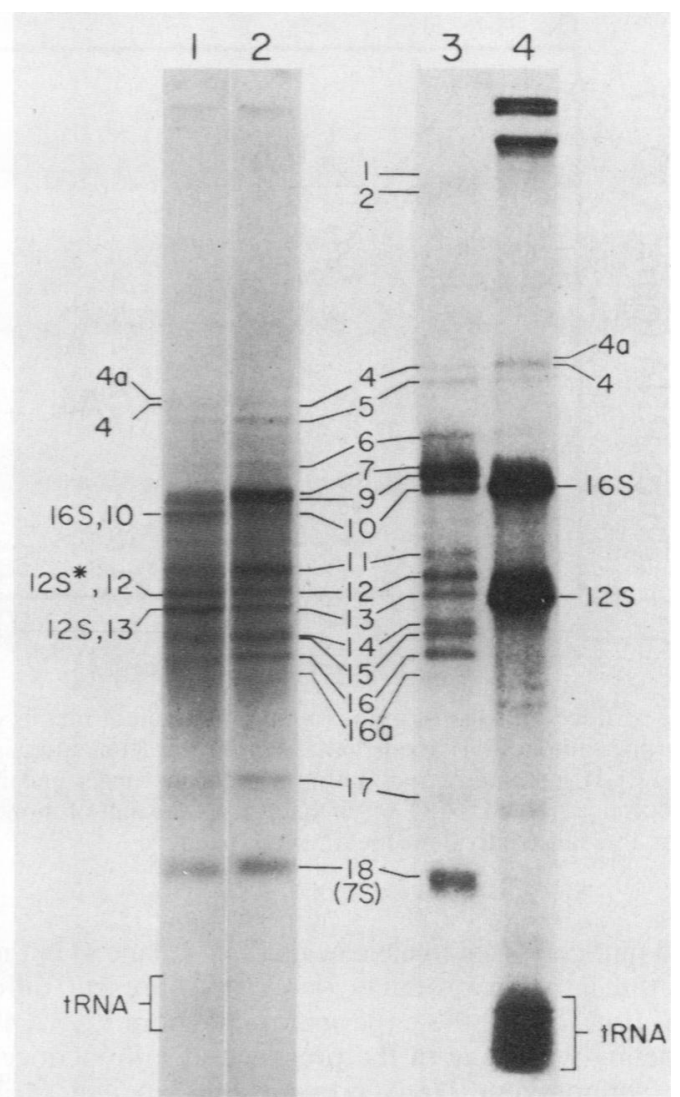

FIG. 2. Comparison of HeLa cell mtDNA transcription in isolated organelles (lanes 1 and 2) and in vivo (lanes 3 and 4). Shown are electrophoretic patterns in agarose- $\mathrm{CH}_{3} \mathrm{HgOH}$ gels of total RNA (lane 1) and oligo(dT)-cellulose-bound RNA (lane 2) from mitochondria labeled in vitro with $\left[\alpha{ }^{-32} \mathrm{P}\right] \mathrm{UTP}$ for $30 \mathrm{~min}$ at $37^{\circ} \mathrm{C}$ and of oligo(dT)-cellulose-bound (lane 3 ) and unbound mitochondrial RNA (lane 4) labeled in vivo with ${ }^{32} \mathrm{P}_{\mathrm{i}}$ for $4 \mathrm{~h}$ in the presence of $0.1 \mu \mathrm{g}$ of actinomycin $\mathrm{D}$ per $\mathrm{ml}$. The sample run in lane 2 was derived from five times the amount of mitochondria as the sample in lane 1: the samples run in lanes 3 and 4 were derived from equivalent amounts of cells.

(Fig. 2, lanes 3 and 4) $(1,20)$. In the present work, a rough estimate of the contribution of mRNAs 12 and 13, respectively, to the overall labeling of the bands formed by (12S* plus 12) RNA and (12S plus 13) RNA was obtained from the labeling of other mRNAs; in fact, almost all mRNAs are known to have very similar steady-state amounts and kinetic properties (13) and have been found to be labeled to a similar extent in vitro under a variety of experimental conditions (12; present work). Furthermore, because of the usually large excess of 16S RNA over the amount of its polyadenylated equivalent, RNA $10(20,26)$ (Fig. 2, lanes 1 and 2), the intensity of the band (16S plus 10 ) has been interpreted to primarily reflect, under standard conditions, the behavior of the mature oligoadenylated large rRNA species (11). The observation that the rRNA species $16 \mathrm{~S}, 12 \mathrm{~S}^{*}$, and $12 \mathrm{~S}$ exhibit a coordinate quantitative behavior under different conditions (see below) supports the validity of the criteria followed here.

The three intensely labeled, slowly moving bands, which are DNase sensitive (data not shown), observed in the pattern of the in vivo-synthesized oligo(dT)-cellulose- 

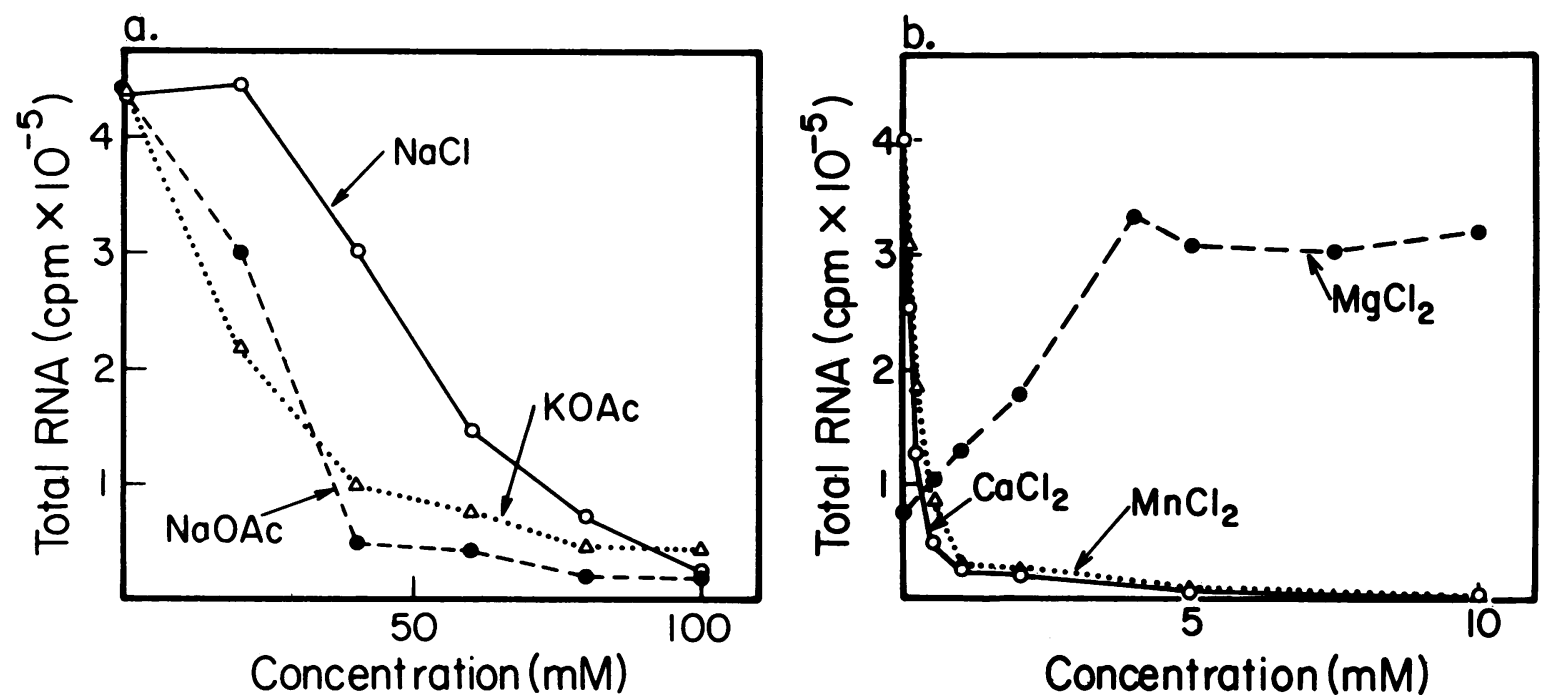

FIG. 3. Effects of salts of monovalent and divalent metals on overall mitochondrial RNA labeling in isolated organelles. The data plotted represent the radioactivity incorporated into total RNA after incubation of mitochondria from $0.5 \mathrm{~g}$ of HeLa cells in the presence of $8 \mu \mathrm{Ci}$ of [ $\left.\alpha-{ }^{32} \mathrm{P}\right] U T P$. The standard incubation conditions described in the text were used, except that in the experiments shown in (a) various concentrations of $\mathrm{NaCl}, \mathrm{NaOAc}$, or $\mathrm{KOAc}$, as the salt of monovalent metal were used, and in (b) various concentrations of $\mathrm{MgCl}_{2}, \mathrm{CaCl}_{2}$, or $\mathrm{MnCl}_{2}$, as the salt of divalent metal, were used.

unbound mitochondrial nucleic acids (Fig. 2, lane 4) but not in that of the in vitro products (lane 1), represent different forms of mtDNA. In the experiment shown in Fig. 2, the in vivo labeling was done in the presence of a low concentration of actinomycin D to prevent the labeling of highmolecular-weight cytoplasmic RNAs. The in vitro-labeled RNA shows no trace of cytoplasmic rRNA, indicating the absence of any contamination of the mitochondrial fraction used here by active nucleolar transcription complexes. In the typical in vitro patterns, particularly in the patterns obtained under nonstandard conditions (see below), one can see some minor unidentified bands, which may represent prematurely terminated or incompletely processed $\mathrm{H}$-strand transcripts or L-strand transcripts; their nature is presently being investigated.

Effects of incubation conditions on RNA labeling in isolated mitochondria. The patterns shown in Fig. 2 were obtained with RNA synthesized in vitro under optimal conditions for mitochondrial RNA labeling, as specified above. Figure 3a shows the effects of various concentrations of $\mathrm{Na}$ and $\mathrm{K}$ salts on the level of $\left[{ }^{32} \mathrm{P}\right] \mathrm{UMP}$ incorporation into RNA in vitro. $\mathrm{NaCl}$ and $\mathrm{KCl}$ affect the incorporation of label into RNA in similar ways. Thus, addition of either salt to $20 \mathrm{mM}$ had either no effect or a slight stimulatory effect on the incorporation of the precursor, whereas higher concentrations progressively reduced the labeling, causing almost complete inhibition at $100 \mathrm{mM}$. NaOAc and KOAc had a more marked inhibitory effect on RNA labeling than $\mathrm{NaCl}$ and $\mathrm{KCl}$ at comparable concentrations, with a 30 to $50 \%$ reduction at 20 $\mathrm{mM}$ and an 80 to $90 \%$ reduction at $40 \mathrm{mM}$ (Fig. 3a). Thus, the anions contributed to the inhibitory effects in the experiments described above. Both the chloride and the acetate salts of $\mathrm{Na}$ and $\mathrm{K}$ affect similarly the labeling of the various RNA species (see Fig. 4). All further experiments were carried out at $20 \mathrm{mM} \mathrm{NaCl}$.

The effects of various concentrations of $\mathrm{CaCl}_{2}, \mathrm{MnCl}_{2}$, and $\mathrm{MgCl}_{2}$ on in vitro labeling of mitochondrial RNA are shown in Fig. 3b. Increasing concentrations of $\mathrm{CaCl}_{2}$ and $\mathrm{MnCl}_{2}$ had progressively inhibitory effects on $\left[{ }^{32} \mathrm{P}\right] \mathrm{UMP}$ incorporation, with both salts suppressing the RNA labeling by more than $90 \%$ at $1 \mathrm{mM}$ and by more than $98 \%$ at $10 \mathrm{mM}$. In contrast to $\mathrm{CaCl}_{2}$ and $\mathrm{MnCl}_{2}$, increasing concentrations of $\mathrm{MgCl}_{2}$ stimulated progressively the in vitro incorporation of [22 P]UMP; this reached a maximum (corresponding to a $400 \%$ increase) at $4 \mathrm{mM} \mathrm{MgCl} 2$ and remained constant at this level up to $10 \mathrm{mM}$. In contrast to $\mathrm{Na}$ and $\mathrm{K}$ salts, $\mathrm{CaCl}_{2}$ and $\mathrm{MnCl}_{2}$ had differential effects on the labeling of the various RNA species (Fig. 4). In particular, the labeling of the rRNA species $\left(16 \mathrm{~S}, 12 \mathrm{~S}^{*}\right.$, and $\left.12 \mathrm{~S}\right)$ was more affected than that of the mRNA species by the addition of increasing concentrations of $\mathrm{MnCl}_{2}$ and $\mathrm{CaCl}_{2}$. Furthermore, there was a progressive increase in the relative amount of the rRNA precursor u4a and of $12 S^{*}$ rRNA $(12,20)$ (Fig. 1), due to inhibition of the 5 '-end processing step which removes the tRNA ${ }^{\text {Phe }}$ and the $5^{\prime}$ leader.

Figure $5 \mathrm{~b}$ shows the effect of varying the $\mathrm{pH}$ of the incubation buffer on in vitro labeling of mitochondrial RNA. A maximum $\left[{ }^{32} \mathrm{P}\right] \mathrm{UMP}$ incorporation into total RNA was observed at about $\mathrm{pH} 7.5$ (at $37^{\circ} \mathrm{C}$ ); a very similar $\mathrm{pH}$ dependence curve was found for the labeling of the oligo(dT)-cellulose-bound RNA fraction. Figure 5a shows the electrophoretic patterns of total mitochondrial RNA labeled in vitro at different $\mathrm{pHs}$. There were considerable changes in the RNA patterns with $\mathrm{pH}$. For example, above $\mathrm{pH} 7.5$ (Fig. $5 a$, lanes 3 and 4), there was a decrease in the relative labeling of the higher-molecular-weight RNA species (species $4,4 a, 5,6,7$, and 9), an increase in the background of heterogeneous RNA, and the appearance of new bands slower moving than RNA 17 . These changes are possibly related and may reflect a tendency to degradation or premature termination of the transcripts. The most striking finding, however, was the dramatic increase with $\mathrm{pH}$ (between 6.9 and 7.9) in the relative labeling of RNA 18 (7S RNA) (25) (Fig. 5a and c). Furthermore, there was a progressive decrease with $\mathrm{pH}$ in the labeling of RNA $12 \mathrm{~S}^{*}$ relative to that of 12S RNA (Fig. 5a), suggestive of more effective 5 '-end processing of the $12 \mathrm{~S}$ rRNA precursor. Also, there was a progressive decrease in the labeling of $16 \mathrm{~S}$ RNA and a 


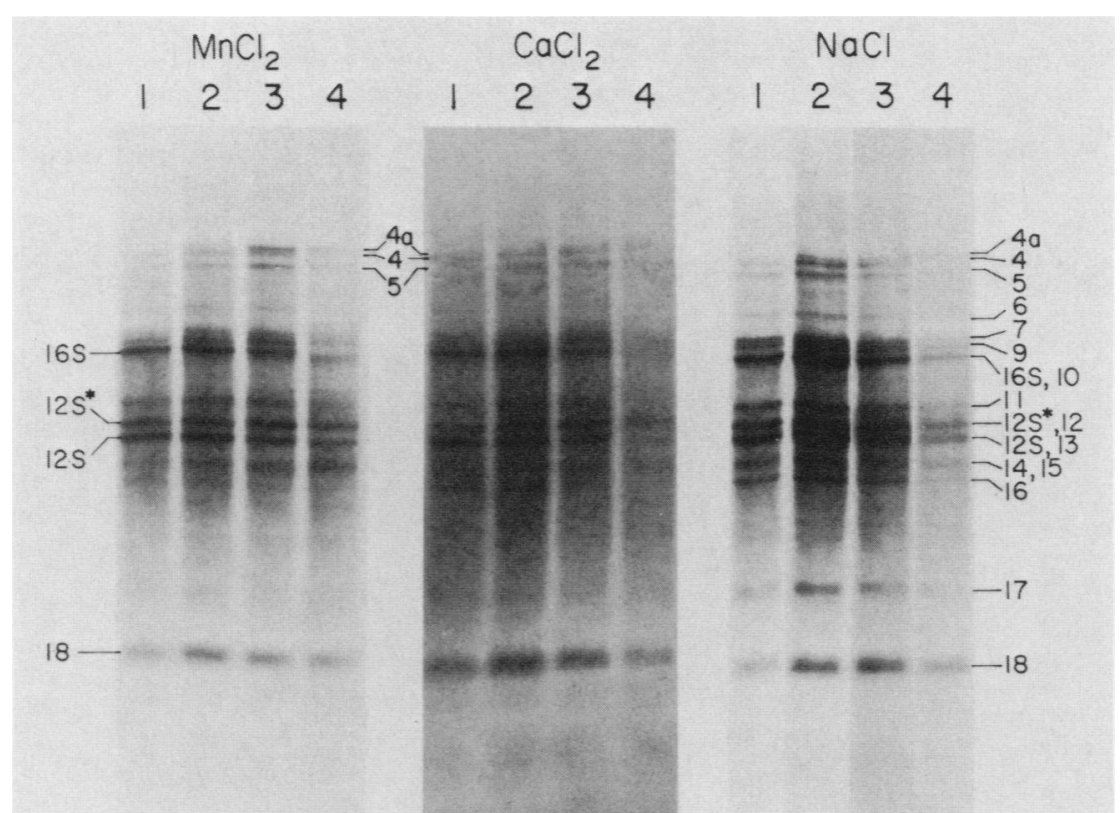

FIG. 4. Electrophoretic patterns of mtDNA transcription products synthesized in isolated organelles in the presence of various concentrations of $\mathrm{MnCl}_{2}, \mathrm{CaCl}_{2}$, or $\mathrm{NaCl}$. Conditions were as specified in the legend for Fig. 3. In the experiments shown in the left $\left(\mathrm{MnCl}_{2}\right)$ and middle $\left(\mathrm{CaCl}_{2}\right)$ panels, the concentrations of the salt tested were $0,100,200$, and $500 \mu \mathrm{M}$, respectively, in lanes 1 through 4 . In the experiment shown in the right panel $(\mathrm{NaCl})$, the salt concentrations were $0,20,60$, and $100 \mathrm{mM}$, respectively, in lanes 1 through 4 . The relative amounts of RNA electrophoresed were $1,2,4$, and 8, respectively, in lanes 1 through 4 of the left panel, and $1,1,3$, and 6 , respectively, in lanes 1 through 4 of the middle panel; equal amounts of material were run in the four lanes of the right panel.

corresponding increase in the labeling of a component (appearing as a fairly broad band) which migrates slightly faster than mRNA 16. This component corresponds in migration to a previously described polyadenylated species (RNA 16a; reference 1) (see also Fig. 2), which represents prematurely terminated 16S RNA (12) (see below). Hybridization experiments with RNA labeled at different pHs and an excess of $\mathrm{H}$ strands or $\mathrm{L}$ strands showed that, in contrast to the behavior of 7S RNA, the proportion of labeled L-strand transcripts in the total RNA remained relatively constant over the $\mathrm{pH}$ range of 7.1 to 7.9 (at $37^{\circ} \mathrm{C}$ ) (Fig. $5 \mathrm{c}$ ).

Figure 6a shows the effects on RNA labeling of varying the CTP, GTP, UTP, and ATP concentrations over the range of 0 to $5 \mathrm{mM}$. Clearly different effects were produced by the four nucleoside triphosphates (NTPs). Increasing concentrations of both CTP and GTP progressively reduced to similar extents the incorporation of label into RNA. A more marked depression of $\left[{ }^{32} \mathrm{P}\right] U \mathrm{UP}$ incorporation was produced by the addition of increasing amounts of UTP above $0.01 \mathrm{mM}$, whereas the reduction of labeling by this nucleotide was negligible at lower concentrations (see Fig. 6a insert). To discriminate within the UTP effect between inhibition of incorporation of the labeled precursor and the consequence of dilution of the specific activity of $\left[\alpha-{ }^{32} \mathrm{P}\right] \mathrm{UTP}$, a parallel experiment was carried out by using $\left[\alpha-{ }^{32} \mathrm{P}\right] \mathrm{CTP}$ as a labeled precursor and various amounts of unlabeled UTP. The inhibition curve thus obtained was very similar to that observed for the inhibition of $\left[{ }^{32} \mathrm{P}\right] \mathrm{UMP}$ incorporation by GTP (data not shown). Therefore, the three NTPs GTP, CTP, and UTP appeared to have very similar inhibitory effects on RNA labeling. In the case of UTP, the major portion of the reduction of $\left[{ }^{32} \mathrm{P}\right] \mathrm{UMP}$ incorporation produced by unlabeled UTP was due to the decrease in specific activity of the labeled precursor (Fig. 6a). However, this reduction was much less than expected from the dilution factor corresponding to each UTP concentration. This suggested that the intramitochondrial UTP pool was large compared with the amount taken in and, furthermore, that there was an increased uptake of exogenous UTP with increasing UTP concentrations, due to the more favorable concentration differential (see below). Gel analysis of the RNA products showed no differential effects of the addition of CTP, GTP, and UTP on the labeling of the various RNA species (data not shown).

In contrast to the effect of the NTPs mentioned above, addition of increasing concentrations of ATP stimulated RNA labeling in isolated mitochondria, with a maximum at 1 to $2 \mathrm{mM}$ (Fig. 6a); at higher concentrations, the stimulatory effect decreased and disappeared at $5 \mathrm{mM}$. A control experiment with $[\alpha-32$ P]ATP showed that at least $50 \%$ of the $1 \mathrm{mM}$ ATP originally present in the incubation medium could still be recovered from the medium as ATP after $30 \mathrm{~min}$ of incubation of the organelles at $37^{\circ} \mathrm{C}$. A differential effect of ATP addition on $\left[{ }^{32} \mathrm{P}\right]$ UMP incorporation into total RNA and into oligo(dT)-cellulose-bound RNA was observed. The relative labeling of the oligo(dT)-cellulose-bound RNA increased at high ATP concentrations ( $>1 \mathrm{mM}$ ) (Fig. 7b). Gel analysis of the oligo(dT)-cellulose-bound RNA species labeled in the presence of different ATP concentrations (Fig. 7a) revealed a parallel behavior of the labeling of the various RNA species; however, at the highest concentration $(5 \mathrm{mM})$, there was a dramatic drop in the labeling of 7S RNA (RNA 18) (Fig. 7a and c) and an increase in the relative labeling of 16S RNA, with the concomitant disappearance of the putative 16a RNA band. Hybridization experiments with RNA labeled in the presence of different ATP concentrations and an excess of $\mathrm{H}$ strands or L strands showed that the amount of labeled Lstrand transcripts varied roughly in proportion to the total 


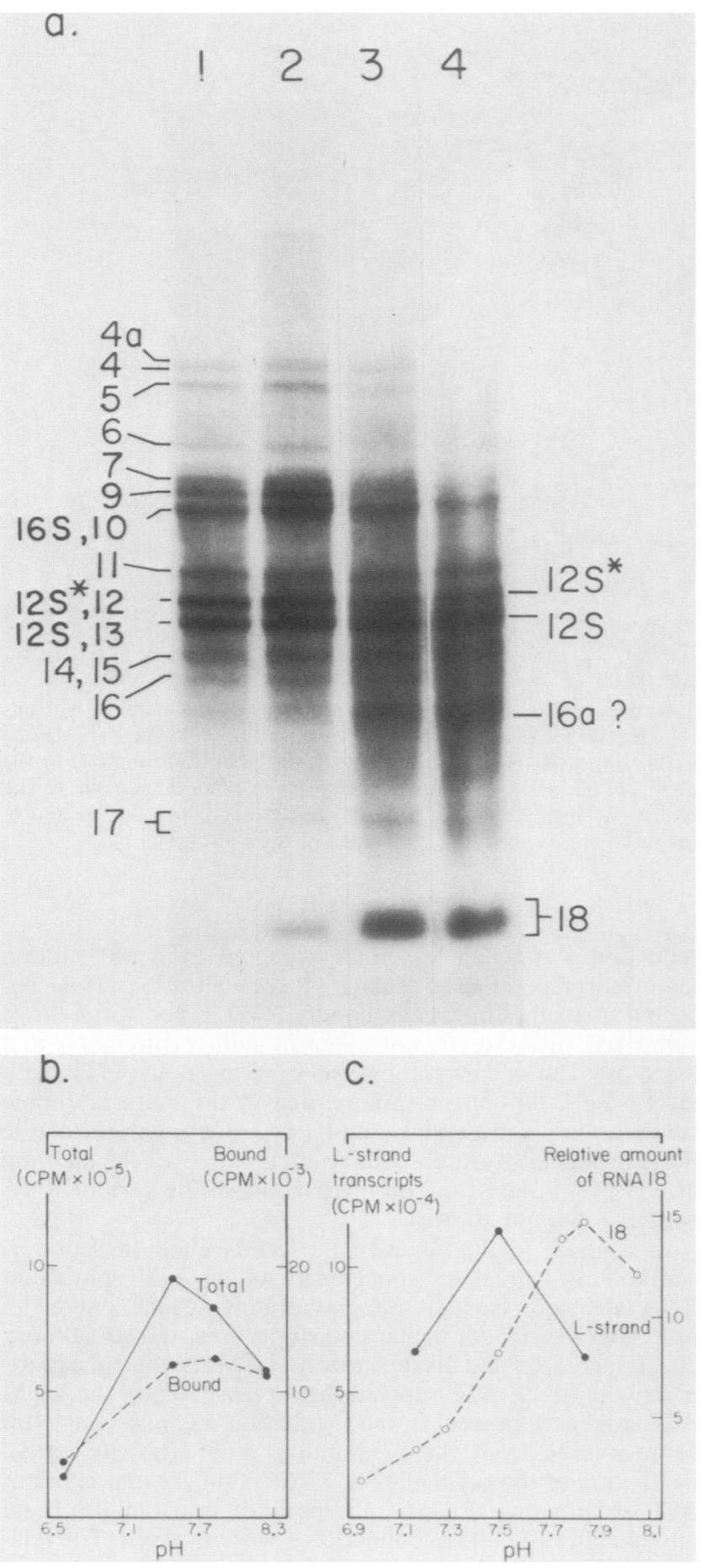

FIG. 5. Effects of $\mathrm{pH}$ on mtDNA transcription in isolated organelles. (a) Autoradiogram after electrophoresis through an agarose$\mathrm{CH}_{3} \mathrm{HgOH}$ gel of mtDNA transcription products labeled in vitro in transcription assays carried out at $\mathrm{pH} 6.95,7.3,7.75$, and 8.05, respectively, in lanes 1 through 4 . Equal amounts of RNA were run in all four lanes. (b) Radioactivity incorporated into total RNA or oligo(dT)-cellulose-bound RNA at different pHs. (c) Effect of pH on the in vitro labeling of L-strand transcripts, as determined by solution hybridization with separated mtDNA strands, and of RNA species 18 (7S RNA), as determined by densitometric measurements on the autoradiograms (arbitrary units). The L-strand transcripts were analyzed in a different experiment from that shown in (b). The $\mathrm{pHs}$ indicated in the graphs were measured at $37^{\circ} \mathrm{C}$. labeled RNA (Fig. 7c). Particularly significant is the observation that, with the ATP concentration in the medium increasing from 1 to $5 \mathrm{mM}$, the labeling of L-strand transcripts decreased by a factor of $\sim 2$, whereas the labeling of $7 S$ RNA decreased by a factor of $\sim 5$.
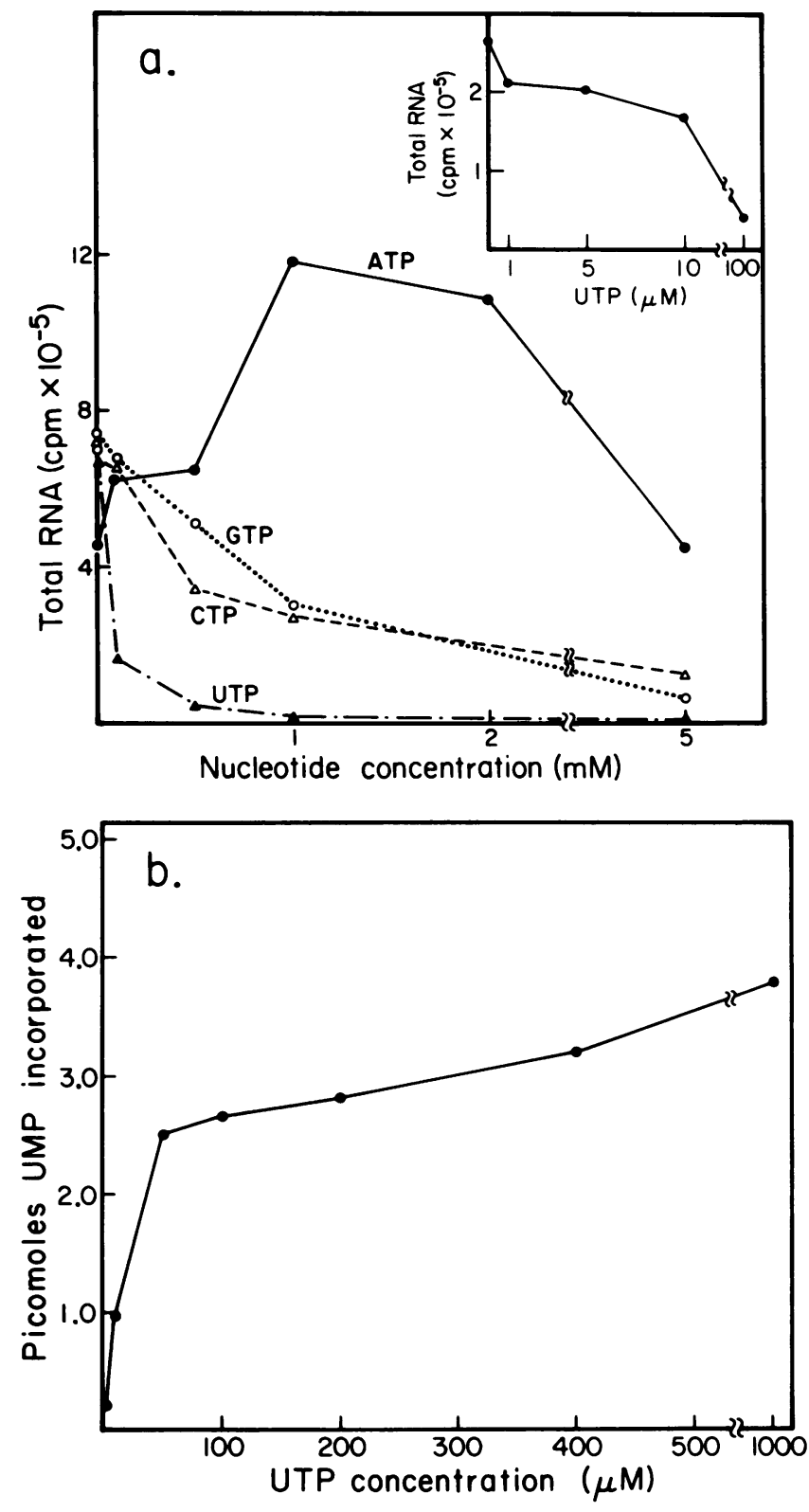

FIG. 6. Effects of NTP concentration on mtDNA transcription in isolated organelles. (a) Experiments testing the effects of various amounts of unlabeled UTP, CTP, or GTP in the presence of $1 \mathrm{mM}$ ATP or the effects of different ATP concentrations in the absence of the other NTPs on RNA labeling with $\left[\alpha{ }^{-32}\right.$ P]UTP $(20 \mu \mathrm{Ci} /$ $\mathrm{ml}$ ); the insert shows in expanded form the effects of low concentrations of UTP on RNA labeling in an experiment similar to that illustrated in the main portion of the panel. (b) In vitro incorporation of UMP into mitochondrial RNA during $30 \mathrm{~min}$ of incubation of mitochondria in the presence of different UTP concentrations in the medium. The data have been calculated from the radioactivity incorporated into total RNA on the basis of the precursor specific activity at each UTP concentration and normalized to $10^{6}$ cell equivalents $\left(\left[\alpha-{ }^{32} \mathrm{P}\right] \mathrm{UTP}\right.$ was present in all assays at $\left.17.8 \mu \mathrm{Ci} / \mathrm{ml}\right)$. 

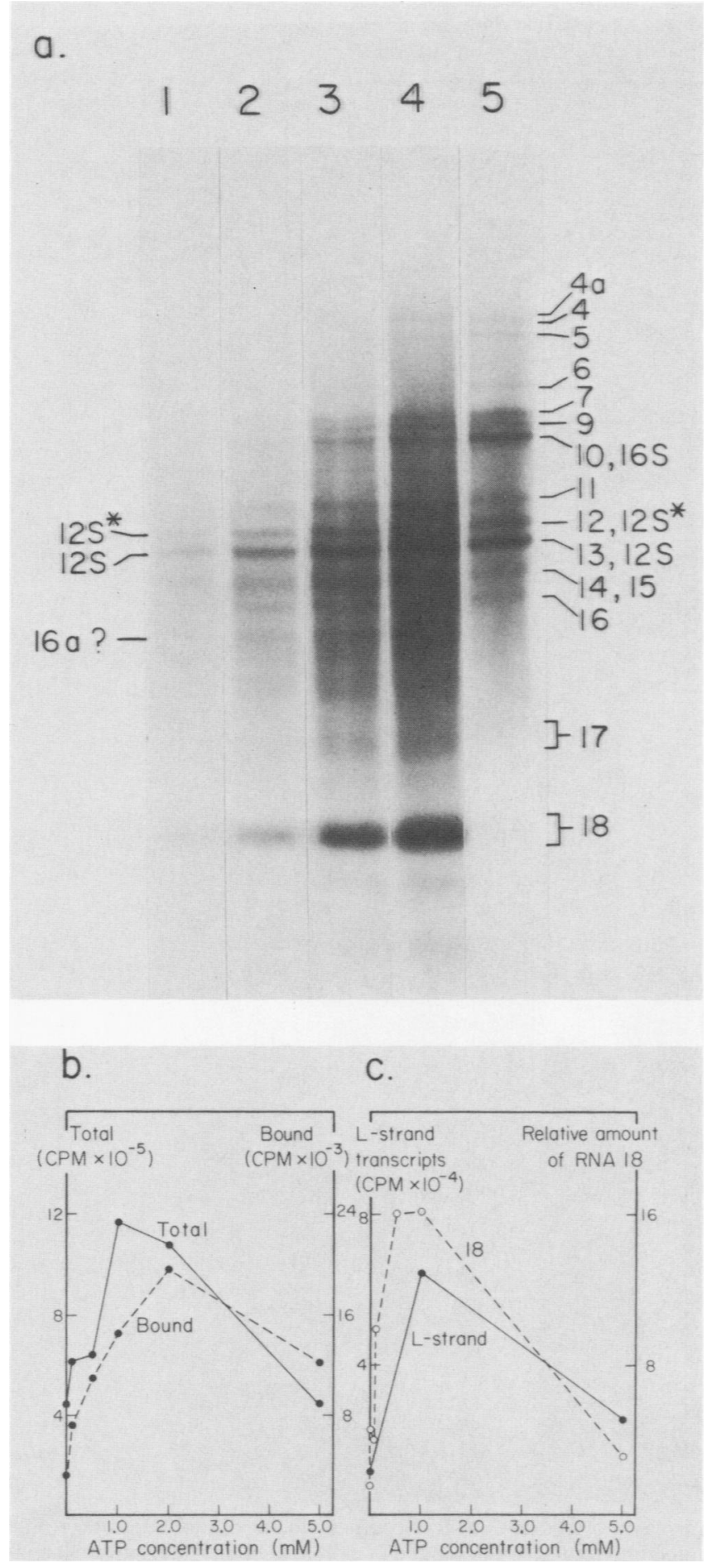

FIG. 7. Effects of ATP concentration on mtDNA transcription in isolated organelles. (a) Autoradiogram after electrophoresis through an agarose- $\mathrm{CH}_{3} \mathrm{HgOH}$ gel of transcription products labeled in the presence of $0,0.01,0.1,1$, and $5 \mathrm{mM}$ ATP, respectively, in lanes 1 through 5. Equal amounts of material were run in the five lanes. (b) Radioactivity incorporated into total RNA or oligo(dT)-cellulosebound RNA in the presence of different ATP concentrations. (c) Effects of various ATP concentrations on the in vitro labeling of $L$ strand transcripts and of RNA species $18(7 \mathrm{~S})$, determined as explained in the legend for Fig. 5. The L-strand transcripts were analyzed in a different experiment from that shown in (b).
The effect of varying the mitochondrial concentration on in vitro labeling of mitochondrial RNA is shown in Fig. 8a. The data are expressed in terms of counts per minute per milligram of protein; a relative mitochondrial concentration of 1 (i.e., the mitochondria from $1 \mathrm{~g}$ of packed cells resuspended in $1 \mathrm{ml}$ of medium) equals about $1.3 \mathrm{mg}$ of mitochondrial protein per $\mathrm{ml}$. The incorporation of label into RNA per mitochondrion decreased slightly $(\sim 30 \%)$ as the relative mitochondrial concentration increased from 0.1 to 1 ; further increases in mitochondrial concentration caused an almost proportional decrease in RNA labeling per mitochondrion. This decrease in labeling could not be due to an increase in overall protein concentration, since a BSA concentration more than sevenfold greater than the unit mitochondrial protein concentration used had no inhibitory effect (Fig. 8b); on the contrary, addition of BSA to $1 \mathrm{mg} / \mathrm{ml}$ increased labeling approximately twofold, suggesting a possible stabilization of mitochondria by nonspecific protein.

At $37^{\circ} \mathrm{C}$, the incorporation of $\left[{ }^{32} \mathrm{P}\right]$ UMP into RNA was linear for ca. $30 \mathrm{~min}$ and then plateaued (Fig. 9a). In another experiment (data not shown), RNA labeling reached a plateau at ca. $45 \mathrm{~min}$. In an experiment in which mitochondria were exposed to $\left[\alpha-{ }^{32} \mathrm{P}\right] U T \mathrm{~T}$ during a 30 -min interval starting immediately after centrifugal separation or after a 15 - or 30 min preincubation in the absence of labeled precursor, the relative amounts of radioactivity incorporated into the three RNA samples were $9,3.5$, and 1 , respectively. At $21^{\circ} \mathrm{C}$, RNA labeling in isolated organelles proceeded at a much lower rate but remained approximately linear for at least $2 \mathrm{~h}$. An analysis of the labeling of gel fractionated mitochondrial RNA species after different times of incubation of mitochondria at $37^{\circ} \mathrm{C}(10,20$, and $30 \mathrm{~min})$ showed a parallel increase in the radioactivity incorporated into the various species (data not shown). Likewise, the labeling patterns of the RNA from mitochondria exposed to $\left[\alpha-{ }^{32}\right.$ P]UTP after different times of preincubation in the absence of labeled precursor, as mentioned above, were very similar (data not shown). Particularly significant was the constancy in the relative labeling of the rRNAs, mRNAs, and 7S RNA, which are the products of three distinct transcription units $(19,20,25)$; also remarkable was the similarity in the relative labeling, at different times, of mRNAs $5,7,9,11$, and 14 through 16 , which are encoded
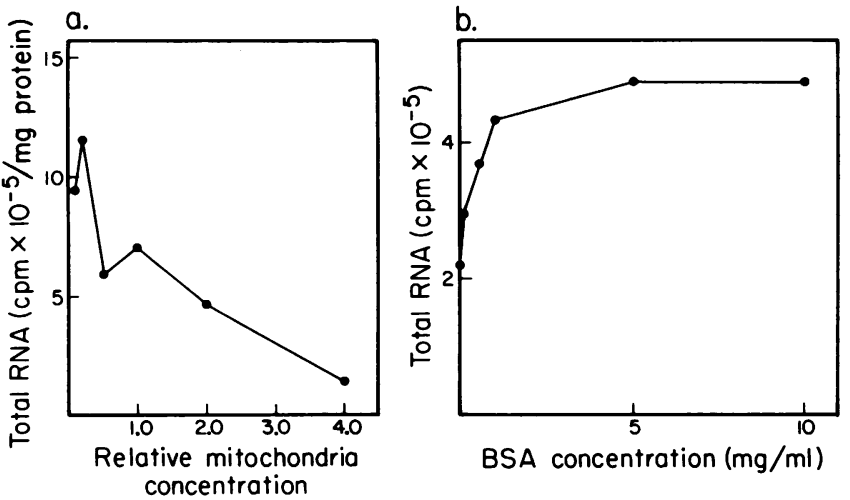

FIG. 8. Effects of mitochondrial or BSA concentration on mtDNA transcription in isolated organelles. (a) Radioactivity incorporated into total RNA in in vitro assays utilizing various concentrations of mitochondria. The radioactivity data have been normalized to $1 \mathrm{mg}$ of mitochondrial protein. (b) Radioactivity incorporated into total RNA in the presence of different BSA concentrations in the incubation medium. 

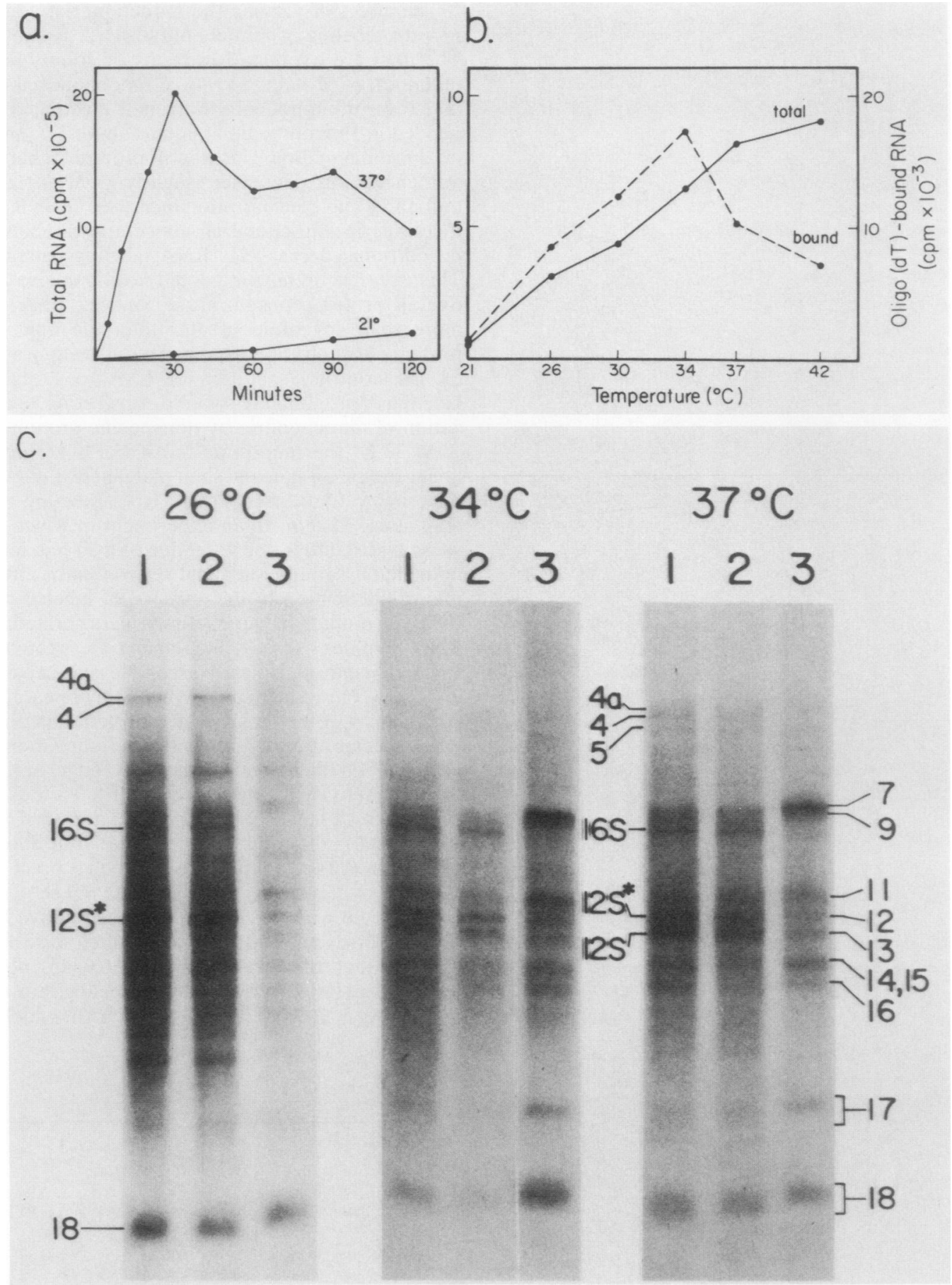

FIG. 9. Effects of incubation temperature on mtDNA transcription in isolated organelles. (a) Radioactivity incorporated into total RNA after different times of incubation at 37 or $21^{\circ} \mathrm{C}$. (b) Radioactivity incorporated into total RNA or oligo(dT)-cellulose-bound RNA after 30 min of incubation at different temperatures. (c) Autoradiogram after electrophoresis through an agarose- $\mathrm{CH}_{3} \mathrm{HgOH}$ gel of total $\mathrm{RNA}$ (lane 1), oligo(dT)-cellulose-unbound RNA (lane 2), and oligo(dT)-cellulose-bound RNA (lane 3 ) labeled at 26,34 , or $37^{\circ} \mathrm{C}$. Relative amounts of material electrophoresed in lanes 1 through 3 were 1,1 , and 10 , respectively, in the left panel and 1,1 , and 40 , respectively, in the middle and right panels.

in different regions of the $\mathrm{H}$ strand. Fractionation on oligo(dT)-cellulose of mitochondrial RNA labeled in vitro at different temperatures revealed that the proportion of labeled RNA which was retained on oligo(dT)-cellulose increased below $37^{\circ} \mathrm{C}$, with a maximum at $34^{\circ} \mathrm{C}$ (Fig. $9 \mathrm{~b}$ and c). As previously observed (12), incubation at temperatures below $37^{\circ} \mathrm{C}$ resulted in an increased proportion of label in $12 \mathrm{~S}^{*}$ RNA relative to $12 \mathrm{~S}$ RNA and in RNA u4a relative to RNA u4 (Fig. 9c), a phenomenon which reflects the cold sensitivity of the step involved in the removal of the tRNA ${ }^{\text {Phe }}$ and 5' 
leader from the rRNA precursors (Fig. 1). The significance of the pronounced labeling of band 7 in the oligo(dT)cellulose-bound RNA labeled at 34 or $37^{\circ} \mathrm{C}$ (Fig. 9c) is not clear. Experiments are in progress to ascertain whether this observation reflects a more efficient polyadenylation of mRNA 7 or the comigration with the latter RNA of another as yet unidentified RNA species.

In vitro mtDNA transcription rate. As discussed above, dilution of $\left[\alpha-{ }^{32}\right.$ P]UTP with unlabeled UTP does not cause a proportional decrease in the incorporation of label and thus results in an increase in the measured amount of total UMP incorporated. The curve measuring the apparent incorporation of total UMP into RNA as a function of external UTP concentration shows near-saturation at ca. $1 \mathrm{mM}$ UTP. One can derive a minimum estimate of the rate of RNA synthesis in vitro from the highest level of the total UMP incorporation curve ( $\sim 4 \mathrm{pmol} / 30 \mathrm{~min}$ per $10^{6}$ cell equivalents), assuming a negligible dilution by the intramitochondrial UTP pool of the exogenous UTP imported into the organelles. Considering that the $\mathrm{H}$ - and L-strand transcripts are labeled in vitro to a similar extent (the observed ratio of label in $\mathrm{H}$ - and L-strand transcripts was $\sim 1.3$ ) and that the average transcript therefore has close to $27 \% \mathrm{U}$ content (average of the $\mathrm{T}$ content of the $\mathrm{H}$ and $\mathrm{L}$ strands [2]), one can calculate a minimum rate of incorporation into RNA of $\sim 0.5 \mathrm{pmol}$ of NTS per $\mathrm{min} / 10^{6}$ cell equivalents.

In vitro initiation of transcription. The results described above did not provide any information as to whether initiation of transcription occurs in the present in vitro system and, if so, to what extent it accounts for the observed labeling patterns. To answer these questions, experiments utilizing the four $\left[\gamma^{-32} \mathrm{P}\right]$ NTPs as labeled precursors were done. These failed to show any specific labeling of discrete RNA species. A very low level of labeling of the normal set of mitochondrial RNA species was observed with all four [ $\gamma$ $\left.{ }^{32} \mathrm{P}\right] \mathrm{NTPs}$, as well as with ${ }^{32} \mathrm{P}_{\mathrm{i}}$, suggesting the existence of intra- or extra-mitochondrial kinase activity. As an alternative approach to investigate the occurrence of initiation of transcription of the rRNA genes in isolated mitochondria, the labeling of the $5^{\prime}$-end-proximal segments of $12 \mathrm{~S}^{*}$ and $12 \mathrm{~S}$ RNA encoded in the MboI-9 fragment of human mtDNA (188 and 92 NTs long, respectively) was compared with that of their 3'-end-proximal segments encoded in the MboI-4 fragment (374 NTs long) (Fig. 1). The S1 protection technique was used to isolate these RNA segments. As expected, hybridization with mp8-M9H (an M13 vector containing the $\mathrm{H}$ strand of the $\mathrm{MboI}-9$ fragment) protects from S1 digestion an $\sim 188$-NT segment of $12 \mathrm{~S}^{*}$ RNA (lane 1) and an $\sim 92-\mathrm{NT}$ segment of 12S RNA (Fig. 10a, lane 3) (a 188-NT band in the latter hybridization reflects contamination of $12 \mathrm{~S}$ RNA by 12S* RNA); mp8-M4H (an M13 vector carrying the $\mathrm{H}$ strand of the MboI-4 fragment) protects an $374-\mathrm{NT}$ segment of both $12 \mathrm{~S}^{*}$ and $12 \mathrm{~S}$ RNA (lanes 2 and 4 ).

To quantitate the labeling of the protected RNA segments, an experiment similar to that shown in Fig. 10a was carried out in which $12 S^{*}$ and $12 S$ RNA, labeled with $\left[\alpha-{ }^{32}\right.$ P]UTP for $30 \mathrm{~min}$ at $37^{\circ} \mathrm{C}$ and purified by two successive $\mathrm{CH}_{3} \mathrm{HgOH}$ agarose gel runs, were each hybridized with a large excess of an equimolar mixture of mp8-M9H and mp8-M4H; after S1 digestion, the protected fragments were isolated on a polyacrylamide-urea gel, eluted, and counted.

Exclusive in vitro labeling of $12 \mathrm{~S}^{*}$ and $12 \mathrm{~S}$ RNA due to de novo initiation would result in the labeling of their $5^{\prime}$-endand 3'-end-proximal segments in proportion to their $U$ content (46 and $28 \mathrm{U}$, respectively, in the $12 \mathrm{~S}^{*}$ and 12S RNA segments protected by $\mathrm{MboI}-9 \mathrm{H}[12 \mathrm{~S} * / \mathrm{Mbol}-9 \mathrm{H}$ and $12 \mathrm{~S} /$
$M b o \mathrm{I}-9 \mathrm{H}]$ and $81 \mathrm{U}$ in $12 \mathrm{~S} * / \mathrm{MboI}-4 \mathrm{H}$ or $12 \mathrm{~S} / \mathrm{MboI}-4 \mathrm{H})(2)$. A different situation would prevail if $100 \%$ of the in vitro labeling of $12 \mathrm{~S}^{*}$ and $12 \mathrm{~S}$ RNA were due to elongation of chains initiated in vivo. This is illustrated schematically for 12S* RNA in Fig. 10b. Assuming an equal spacing of the RNA polymerase molecules along the transcribed DNA segment, the ratio of radioactivity in $12 \mathrm{~S} * \mathrm{MboI}-9 \mathrm{H}$ and $12 \mathrm{~S}^{*} / \mathrm{MboI}-4 \mathrm{H}$ would be 0.062 (see the legend of Fig. 10 for details). The proportion of labeling of $12 S^{*}$ RNA due to de novo initiation or elongation can be calculated by solving the two equations:

$$
\begin{gathered}
\text { cpm in } 12 * \mathrm{~S} / \mathrm{MboI}-9 \mathrm{H}=0.062 x+0.57 y \\
\mathrm{cpm} \text { in } 12 \mathrm{~S} * / \mathrm{MboI}-4 \mathrm{H}=x+y
\end{gathered}
$$

where $x$ and $y$ are, respectively, the radioactivity of the $3^{\prime}$ terminal segment due to elongation and initiation, 0.062 is the value described above, and 0.57 is the ratio of 46 to $81 \mathrm{U}$. The ratio of $0.57 y$ to $0.062 x$ then gives the ratio of radioactivity from initiation to that from elongation in the $5^{\prime}$ terminal segment. The experimental value for the latter ratio was $~ 7.6$. Considering that the specific activity of the elongated $5^{\prime}$ segments is one-half that of the de novoinitiated segments (Fig. 10b), one can calculate that $\sim 80 \%$ of the 12S* RNA molecules completed in vitro are due to de novo initiation. A similar calculation for $12 \mathrm{~S}$ RNA shows that $\sim 30 \%$ of the $12 \mathrm{~S}$ RNA molecules completed in vitro are initiated de novo. In this experiment, the 12S RNA molecules represented $\sim 50 \%$ of the total $12 \mathrm{~S}$ RNA gene transcripts and were derived presumably from processing of 12S* RNA molecules. Under the reasonable assumption that these 12S RNA molecules were the "oldest," i.e., including all those already started in vivo, it is not surprising that the proportion of de novo-initiated 12S RNA molecules was significantly lower than that of $12 \mathrm{~S}^{*}$ RNA molecules. With the caution imposed by the constraints placed in the above calculations, in particular by the assumption of an equal spacing of the RNA polymerase molecules along the transcribed DNA segments, the available evidence indicates that a major portion $(>50 \%)$ of the transcription of the $12 \mathrm{~S}$ RNA gene in vitro reflects de novo initiation events.

\section{DISCUSSION}

The most important outcome of the present work has been the demonstration of the capacity of isolated HeLa cell mitochondria to support DNA transcription and RNA processing in a way closely reproducing the in vivo events and at rates approaching the in vivo rates. Such a capacity has allowed the analysis of the role of different parameters on these processes without the constraints imposed by the nucleo-cytoplasmic compartment. As described in this paper, the efficiency and fidelity of mitochondrial RNA synthesis in isolated organelles should make this a valuable system for future studies on the control by the nucleus and cytoplasm of mitochondrial gene expression.

Requirements for RNA synthesis in isolated mitochondria. Although the energetic requirements of the in vitro system described here have not been analyzed in detail, it is clear that RNA synthesis in this system is dependent to a considerable extent on an external ATP source. In different experiments, isolated mitochondria were capable of supporting only 10 to $35 \%$ of their RNA synthetic capacity in the absence of any added ATP. It seems likely that, in the absence of exogenous ATP, isolated organelles utilize ATP produced endogenously through oxidative phosphorylation. Addition to the incubation medium of a respiratory substrate 


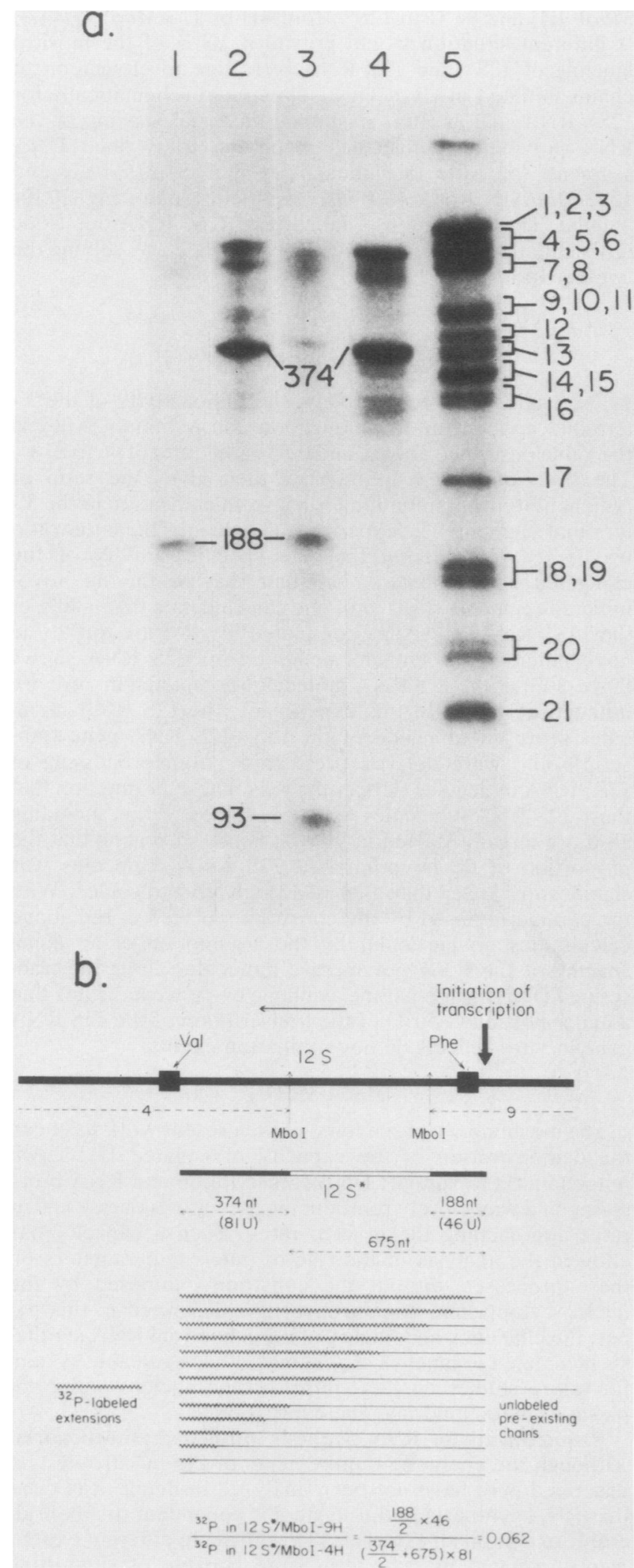

FIG. 10. Initiation of mtDNA transcription in isolated organelles. (a) Isolation by $S 1$ protection of the 5'-end-proximal and $3^{\prime}$ end-proximal segments of $12 \mathrm{~S}^{*}$ and $12 \mathrm{~S}$ RNA. 12S* and 12S RNA, in vitro labeled with $\left[\alpha-{ }^{32} \mathrm{P}\right] \mathrm{UTP}$, were isolated by two consecutive electrophoretic runs and each hybridized with an excess of $M b o l-9 \mathrm{H}$ (pyruvate, citrate, $\alpha$-ketoglutarate, or succinate), alone or in combination with ADP and $P_{i}$, in place of ATP, has produced variable stimulation of RNA labeling, in some cases up to the level produced by exogenous ATP (unpublished data).

The optimum incubation conditions found for the various RNA synthesis and processing steps occurring in isolated mitochondria probably reflect in good part the ionic, $\mathrm{pH}$, and NTP requirements of the corresponding individual enzymatic reactions. In fact, the membrane potential generated by ATP hydrolysis or respiration was probably adequate to support import of cations or NTs into the organelles in proportion to their external concentration $(16,17)$. It is interesting that the optimum values for the concentrations of $\mathrm{NaCl}, \mathrm{KCl}, \mathrm{Mg}^{2+}$, and ATP as well as for $\mathrm{pH}$ found in the present work for the overall RNA synthetic capacity of isolated organelles are reasonably close to those determined for mtDNA transcription in an in vitro soluble system derived from HeLa cell mitochondria (D. Shuey and G. Attardi, manuscript in preparation). By contrast, the divalent cations $\mathrm{Ca}^{2+}$ and $\mathrm{Mn}^{2+}$ had at comparable concentrations a much more drastic inhibitory effect on RNA synthesis in isolated organelles than in the soluble system. This may reflect the high uptake capacity for $\mathrm{Ca}^{2+}$ and $\mathrm{Mn}^{2+}$ which mitochondria possess due to the existence of a specific translocation system (29), and therefore the higher effective concentrations of these ions reached inside the organelles.

The relatively high ATP optimum concentration found for RNA synthesis in isolated organelles (1 to $2 \mathrm{mM}$ ) does not appear to be due to its rapid degradation in the in vitro system, since about $50 \%$ of the exogenous ATP could be recovered as such from the medium even after $30 \mathrm{~min}$ of incubation at $37^{\circ} \mathrm{C}$. Based on the reported distribution of ATP in different subcellular fractions of HeLa cells (5) and on the fraction of the cell volume occupied by mitochondria in these cells $(\sim 10.5 \%)(28)$, the concentration of ATP in HeLa cell mitochondria can be estimated to be ca. $\sim 0.8 \mathrm{mM}$, i.e., close to the optimum ATP concentration observed here. It is interesting that a relatively high ATP optimum concentration for mitochondrial RNA synthesis $(0.5$ to $1 \mathrm{mM})$, with a sharp decrease in synthesis below $0.1 \mathrm{mM}$, has also been found in the soluble system mentioned above from HeLa cell mitochondria (Shuey and Attardi, in preparation). It is not possible at present to say whether the high ATP optimum

or $M b o I-4 \mathrm{H}$ (Fig. 1); after $\mathrm{S} 1$ digestion, the protected segments were separated by electrophoresis through an $8 \%$ polyacrylamide- $8 \mathrm{M}$ urea gel. Lanes 1 and 2, 12S* RNA segments protected by $M$ bol-9H and $M b o l-4 \mathrm{H}$, respectively; lanes 3 and 4, 12S RNA segments protected by $M b o \mathrm{I}-9 \mathrm{H}$ and $M b o \mathrm{I}-4 \mathrm{H}$, respectively; lane 5, 3'-endlabeled mtDNA HpaII digest marker. (b) Scheme illustrating the rationale for estimating the relative levels of labeling of the $5^{\prime}$-endproximal and 3'-end-proximal segments of $12 S^{*}$ RNA under the assumptions of no in vitro initiation and uniform spacing of RNA polymerase along the transcribed mtDNA segment. In particular, under these assumptions the radioactivity in the $5^{\prime}$-end-proximal segment of 12S* RNA would be a function of the average length of the labeled NTP stretches corresponding to this segment multiplied by the number of U's that it contains (ignoring any inhomogeneity in $\mathrm{U}$ distribution); similarly, the radioactivity in the $3^{\prime}$-end-proximal segment would be a function of the average length of the labeled stretches corresponding to this segment plus the length of the portion of $12 S^{*}$ upstream of it (the latter component is accounted for by the RNA polymerase molecules sitting on this portion of $12 \mathrm{~S}^{*}$ at the time of addition of label) multiplied by the number of $U$ 's in the 3'-end-proximal segment. 
concentration observed for RNA synthesis in isolated organelles reflects the requirements of the enzymatic machinery involved or a regulatory role of ATP.

The inhibitory effects of CTP, GTP, and UTP on mitochondrial RNA labeling are rather intriguing. It seems possible that they reflect competition by the three NTPs for a common uptake system distinct from the ADP-ATP carrier. Alternatively, the three NTPs may act at the level of the transcriptional machinery. The increase in UTP uptake into HeLa cell mitochondria with increasing concentrations of the NTP in the medium has been found in the present work to offset in part the effect of dilution of the label. The nearsaturation exhibited by the curve measuring the apparent incorporation of total UMP into RNA may indicate that at ca. $1 \mathrm{mM}$ exogenous UTP, the uptake capacity of mitochondria for this NTP is close to its maximum or that the amount of imported NTP has become larger than the size of the mitochondrial UTP pool, or both. It is interesting that on the basis of the intracellular distribution of UTP (5) and the mitochondrial volume (28), the mitochondrial UTP concentration can be estimated to be $\sim 215 \mu \mathrm{M}$, which falls within the near-horizontal portion of the UMP incorporation curve. This estimate makes the second alternative mentioned above more plausible. An increase in the measured levels of UMP incorporation into RNA with increasing concentration of exogenous UTP has been previously reported for isolated HeLa cell mitochondria (Novitski, Ph.D. thesis) and also observed for isolated yeast organelles (6).

The rate of in vitro mitochondrial RNA synthesis approaches the in vivo rate. The rate of RNA synthesis in isolated HeLa cell mitochondria observed in the present work is unusually high for an in vitro system. A rate of incorporation of $\sim 0.5 \mathrm{pmol}$ of NTPs per $\mathrm{min} / 10^{6}$ cell equivalents was estimated from the UMP incorporation in the presence of 1.0 mM UTP and from the postulated $U$ content of the average mtDNA transcript. If the observed inhibitory effect of high UTP concentrations on RNA labeling were due to action on the RNA polymerase(s), a correction for this inhibition would raise the actual rate of nucleotide incorporation to $\sim 0.8 \mathrm{pmol}$ of NTPs per $\mathrm{min} / 10^{6}$ cell equivalents. These rates have to be compared with that of 5 to $7 \mathrm{pmol}$ of NTPs per $\mathrm{min} / 10^{6}$ cell equivalents estimated for the in vivo synthesis of HeLa cell mitochondrial RNA (4). Considering that only 50 to $75 \%$ of the total mitochondrial transcriptional activity was recovered in the centrifugal fraction analyzed in the present work and that no correction was made for possible pool effects, one can estimate that the in vitro synthetic capacity of the present in vitro system is at least 10 to $15 \%$ of the in vivo capacity. An appreciable portion of the decrease in mitochondrial RNA synthetic capacity in isolated organelles appears to be due to depression of rRNA synthesis, which accounts for only 10 to $20 \%$ of the total $\mathrm{H}$-strand transcription (as estimated from densitometric measurements), instead of 85 to $90 \%$, as is the case in vivo (4). The observed absolute rate of UMP incorporation into RNA of isolated HeLa cell mitochondria is comparable to the rates reported for isolated yeast mitochondria $(6,14,22)$.

Under optimal conditions, in vitro labeling of mitochondrial RNA continues at a constant rate for about $30 \mathrm{~min}$ at $37^{\circ} \mathrm{C}$ and then plateaus. The overall kinetics of incorporation of $\left[{ }^{32} \mathrm{P}\right] \mathrm{UMP}$ into RNA probably reflect the changes with time in the rate of RNA synthesis, the rate of RNA decay, and the intramitochondrial UTP pool specific activity. In an experiment in which, after either a 15 - or a 30 -min $\left[\alpha-{ }^{32}\right.$ P]UTP pulse at $37^{\circ} \mathrm{C}$, the cells were further incubated in the presence of a dose of actinomycin $D(8.1 \mu \mathrm{M})$ sufficient to block RNA synthesis almost completely (12), no obvious decline of radioactivity in the rRNA and mRNA species was observed over a period of $105 \mathrm{~min}$ (unpublished data). Under these conditions, therefore, the half-life of the mitochondrial RNA species labeled in vitro appeared to be considerably longer than that previously measured in HeLa cells after a cordycepin block of RNA synthesis (13); thus, RNA decay probably did not play a significant role in determining the shape of the [ $\left.{ }^{32} \mathrm{P}\right] \mathrm{UMP}$ incorporation curve. On the other hand, as mentioned earlier, the in vitro labeling of RNA during a $30-\mathrm{min}$ exposure of mitochondria to $\left[\alpha-{ }^{32} \mathrm{P}\right] \mathrm{RTP}$ after a 30 -min preincubation in nonradioactive medium was only $10 \%$ of that found without preincubation. It seems likely that in the linear portion of the RNA labeling curve, a progressive decrease in RNA synthetic activity is compensated for by the concomitant increase in precursor pool specific activity.

No appreciable change in the pattern of labeling of the various RNA species was observed after up to $60 \mathrm{~min}$ of incubation of isolated mitochondria at $37^{\circ} \mathrm{C}$. This observation indicates that the different transcription and RNA processing events occur in vitro at the same relative rates throughout that period and furthermore that abnormal degradation processes do not play a significant role in generating the patterns observed after up to $60 \mathrm{~min}$ of incubation at $37^{\circ} \mathrm{C}$.

In vitro initiation of mitochondrial RNA synthesis. A substantial fraction of the RNA synthesized in isolated mitochondria is represented by chains initiated in vitro. Direct determinations of the in vitro labeling of the $5^{\prime}$ - and $3^{\prime}$-end portions of the $12 \mathrm{~S}$ rRNA gene transcripts $\left(12 \mathrm{~S}^{*}\right.$ and $12 \mathrm{~S}$ RNA) indicate that $>50 \%$ of these transcripts were generated de novo in the isolated organelles. Although similar determinations were not made for the polycistronic transcripts that start at the downstream $\mathrm{H}$-strand transcription initiation site and produce the mRNAs and most of the tRNAs encoded in the $H$ strand (20), their high rate of labeling, lasting for about $30 \mathrm{~min}$ at $37^{\circ} \mathrm{C}$, indicates that a large fraction of them must have been initiated in vitro. Consistent with this conclusion is the observation that the mRNAs encoded in the 5'-end-proximal half (mRNA 9) and the 5'-end-distal half (such as mRNAs 16, 7, and 11) of the total $\mathrm{H}$-strand transcription unit are labeled to a similar extent. Furthermore, their relative labeling does not change even after $30 \mathrm{~min}$ of preincubation in unlabeled medium. Similar observations on the relative labeling of the L-strandcoded 7S RNA after different times of in vitro incubation strongly suggest that a large fraction of these molecules have been initiated in vitro.

Differential behavior in vitro of rRNA and mRNA synthesis. A distinguishing feature of the in vitro system described in this work, as compared with the in vivo situation, is the considerably lower efficiency and greater lability of rRNA synthesis relative to mRNA synthesis. In view of the evidence discussed in the previous section, it seems likely that the reduced efficiency of rRNA synthesis reflects at least in part a lower rate of initiation of transcription at the rRNA specific promoter under the in vitro conditions. However. the relatively low level of in vitro labeling of $16 \mathrm{~S}$ RNA also points to defects in chain elongation or termination, or both. The ratio of labeling of 16S RNA and (125 plus $\left.12 S^{*}\right)$ RNA $(0.1$ to 0.5$)$ observed under optimal conditions is substantially lower than the value of ca. 1 most frequently found for the labeling ratio of in vivo synthesized $16 \mathrm{~S}$ and $12 \mathrm{~S}$ RNA. (In the latter case, the deviation from the value of $\sim 1.6$ expected for an equimolar synthesis of the two rRNA species is due to 
the particular tendency to degradation of 16S RNA [3].) The lower ratio of labeling of $16 \mathrm{~S}$ RNA to (12S plus $\left.12 \mathrm{~S}^{*}\right)$ RNA under the in vitro conditions does not appear to be due to instability of the newly formed 16S RNA, since the same ratio was found also after a short period of in vitro labeling (10 min). Rather, it may reflect a high probability of premature termination of the rDNA transcripts within the $16 \mathrm{~S}$ RNA gene or a failure of these transcripts to recognize the termination signal at the $3^{\prime}$ end of this gene, or both (11).

The defects in rRNA formation appear to be accentuated under suboptimal conditions for in vitro RNA synthesis. Thus, in previous work (12) actinomycin D, proflavine, and ethidium bromide were found to preferentially inhibit the labeling of the two rRNA species, in particular of 16S RNA, over that of the mRNAs in isolated mitochondria. The same phenomenon has been observed in the present work in the presence of $\mathrm{Mn}^{2+}$ or $\mathrm{Ca}^{2+}$. In the work cited above, the preferential inhibition of 16S RNA labeling in the presence of actinomycin $\mathrm{D}$ was accompanied by a progressive increase in the relative labeling of a component with the same electrophoretic mobility as that of the RNA species 16a previously observed in in vivo-labeled mitochondrial RNA from actinomycin D-treated cells (Fig. 2) (1). The latter RNA has been shown to correspond to a 16S RNA molecule prematurely terminated at about one-third the distance from the $5^{\prime}$ end of the $16 \mathrm{~S}$ rRNA gene (12; J. Montoya, G. Gaines, and G. Attardi, unpublished data). An accumulation of a similarly migrating component, concomitant with a decrease in 16S RNA labeling, has also been observed in the present work in mitochondria incubated at high pHs. Experiments are in progress to determine whether the component with the electrophoretic mobility of RNA 16a observed in vitro does indeed represent prematurely terminated 16S RNA.

The relative abundance in the in vitro-synthesized RNA of the RNA species $12 S^{*}$ and of the rRNA precursor $u 4 a$, both of which still carry at their $5^{\prime}$ end the $\mathrm{tRNA}^{\mathrm{Phe}}$ and leader sequences $(9,12)$, indicates a slowing down of the processing step leading to the removal of these sequences. This slowing down in rRNA processing had been previously observed in isolated mitochondria and found to be accentuated at low temperatures or in the presence of proflavine or ethidium bromide (12). In the present work, an inhibition of the 5'-end processing step was produced by high concentrations of $\mathrm{Ca}^{2+}$ or $\mathrm{Mn}^{2+}$. The $12 \mathrm{~S}^{*}$ RNA species probably also occurs in vivo as a short-lived intermediate. In the electrophoretic pattern of the oligo(dT)-cellulose-unbound mitochondrial RNA from cells labeled in the presence of actinomycin D, the band corresponding to the position of $12 \mathrm{~S}^{*}$ RNA has often been found to be of a somewhat higher intensity than can be accounted for by the expected amount of comigrating mRNA 12: this observation suggests the presence of a small pool of 12S* RNA molecules in the mitochondria of actinomycin D-treated cells. In exponentially growing cells, there is evidence indicating that processing of the primary rDNA transcripts occurs while they are still in the nascent state (4a, 20). However, it is not yet known whether this processing involves the formation of $12 S^{*} \mathrm{RNA}$ as an obligatory intermediate.

The lower efficiency of rRNA formation relative to mRNA synthesis in isolated mitochondria and its particular sensitivity to the incubation conditions probably reflect the more stringent requirements of the processes involved, whether at the level of the initiation reaction, of chain elongation and termination, or of RNA processing. A special role could be played in these processes by the ribosomal proteins. It seems conceivable that the cessation of import of these proteins, or at least of some critical ones among them, from the cytoplasm may be the main factor responsible for the decrease in the rate of initiation of rRNA synthesis, the inefficiency of 5 -end processing, and possibly the defects in chain elongation. Ribosomal proteins may also play a critical role in the attenuation phenomenon leading to the specific termination of the rDNA transcripts at the $3^{\prime}$ end of the $16 \mathrm{~S}$ RNA gene $(4,11)$.

The observations reported in the present and previous work (12) concerning the preferential reduction of rRNA synthesis, especially $16 \mathrm{~S}$ RNA synthesis, in isolated mitochondria relative to the synthesis of the mRNAs encoded in the downstream regions of the $\mathrm{H}$ strand clearly point to independent controls of the two overlapping transcription units which are involved in the synthesis of the rRNAs and mRNAs $(19,20)$. Thus, these results give strong support to the similar conclusion derived from S1 mapping and kinetic experiments carried out with in vivo-synthesized RNA (20).

Polyadenylation reaction in vitro less efficient than in vivo. In vivo the bulk of the individual mRNAs possess a polyadenylate tail 55 to 60 NTPs long $(18,23)$ and are thus retained on oligo(dT)-cellulose (1). By contrast, only 5 to $20 \%$ of each of the mRNAs synthesized in isolated organelles are retained on oligo(dT)-cellulose due to either the absence or the shorter length of the polyadenylate tail. High concentrations of ATP $(>1 \mathrm{mM})$ or temperatures of incubation below $37^{\circ} \mathrm{C}\left(34^{\circ} \mathrm{C}\right.$ or lower $)$ do increase the extent of polyadenylation of mitochondrial RNA, but this still remains below the level observed in vivo. Therefore, the polyadenylate-synthesizing apparatus appears to be relatively more affected under the in vitro conditions than the mtDNA transcription machinery. This implies that the addition of the 55- to 60-NTP-long polyadenylate tail can be dissociated from the processing step which produces the individual mRNAs from the putative polycistronic transcript. However, the present results do not exclude the possibility that the addition of one or a few $A^{\prime} s$ at the $3^{\prime}$ end of the mRNAs and rRNAs is obligatorily coupled with the processing event $(4$, 27).

Dissociation of 7S RNA formation from overall L-strand transcription. The strikingly different behavior of 7S RNA labeling and overall L-strand transcription under different conditions of incubation of isolated mitochondria was an unexpected observation in the present work. This RNA species, $\sim 200$ NTPs long, maps in the region of the genome immediately preceding the origin of replication in the direction of L-strand transcription and possesses a putative ribosome attachment site (25). The function of this unusual RNA species is unknown, although a role in connection with the initiation of mtDNA replication or with the complete transcription of the $L$ strand has been postulated (4). A main L-strand transcription initiation site has been recently localized in human mtDNA near the $5^{\prime}$ end of the 7S RNA coding sequence (25) both by $\mathrm{S} 1$ mapping of in vitro-capped mitochondrial RNA and in vivo-synthesized nascent chains (19) and by in vitro transcription studies (30; Shuey and Attardi, in preparation). Furthermore, the in vivo- and in vitrosynthesized transcripts starting at this initiation site have been found to extend beyond the $3^{\prime}$ end of 7S RNA for up to more than 600 NTPs (Shuey and Attardi, in preparation). These results have suggested the possibility that these transcripts may be a part of the putative fast-turning-over whole L-strand polycistronic transcripts destined to yield by processing the eight tRNA species and the mRNA for the unidentified reading frame (URF) 6 encoded in the $L$ strand (26). According to this view, 7S RNA may also derive from 
processing of these polycistronic transcripts; alternatively, this RNA species may be independently transcribed, starting at a site very close to or even coinciding with the initiation site so far identified.

The results obtained in this work support the idea that $7 \mathrm{~S}$ RNA formation can be independently regulated from whole L-strand transcription. The dramatic drop in 7S RNA labeling at a high ATP concentration $(5 \mathrm{mM})$ could conceivably be due to an accelerated turnover of this species. By contrast, in view of the apparently long half-life of the in vitro-synthesized 7S RNA and the short duration of the experiment, it seems unlikely that the large increase of $7 \mathrm{~S}$ RNA labeling at high $\mathrm{pH}$, which was not accompanied by a proportional increase in L-strand transcription, is due to an increase in stability of this RNA species. Rather, it seems probable that the increase in 7S RNA labeling reflects an increase in 7S RNA formation. However, these experiments cannot distinguish between an effect of the high $\mathrm{pH}$ on a processing event involving a larger precursor, possibly the whole L-strand polycistronic transcript, and an effect on an independent transcription event. As to the mechanism of this phenomenon, it is not possible to say whether the high $\mathrm{pH}$ modifies the internal ionic environment of the organelle or affects the energetic state of the inner mitochondrial membrane.

\section{ACKNOWLEDGMENTS}

These investigations were supported by Public Health Service grants GM-11726 and T32 GM-07616 from the National Institutes of Health.

We are greatly indebted to Michael King for supplying us with M13 clones of human mtDNA. We thank Arger Drew for excellent technical assistance.

\section{LITERATURE CITED}

1. Amalric, F., C. Merkel, R. Gelfand, and G. Attardi. 1978. Fractionation of mitochondrial RNA from HeLa cells by high resolution electrophoresis under strongly denaturing conditions. J. Mol. Biol. 118:1-25.

2. Anderson, S., A. T. Bankier, B. G. Barrell, M. H. L. deBruijn, A. R. Coulson, J. Drouin, I. E. Eperon, D. P. Nierlich, B. A. Roe, F. Sanger, P. H. Schreier, A. J. H. Smith, R. Stader, and I. G. Young. 1981. Sequence and organization of the human mitochondrial genome. Nature (London) 290:457-465.

3. Attardi, B., and G. Attardi. 1971. Expression of the mitochondrial genome in HeLa cells. I. Properties of the discrete RNA components from the mitochondrial fraction. J. Mol. Biol. 55:231-249.

4. Attardi, G., P. Cantatore, A. Chomyn, S. Crews, R. Gelfand, C. Merkel, J. Montoya, and D. Ojala. 1982. A comprehensive view of mitochondrial gene expression in human cells, p. 51-71. In P. Slonimski, P. Borst, and G. Attardi (ed.), Mitochondrial genes. Cold Spring Harbor Laboratory, Cold Spring Harbor, New York.

4a.Attardi, G., G. Gaines, and J. Montoya. 1983. Regulation of ribosomal RNA and messenger RNA synthesis in human mitochondria, p. 107-125. In R. J. Schweyen, K. Wolf, and F. Kaudewitz (ed.), Mitochondria. Walter de Gruyter \& Co., Berlin.

5. Bestwick, R. K., G. L. Moffett, and C. K. Mathews. 1982. Selective expansion of mitochondrial nucleoside triphosphate pools in antimetabolite-treated HeLa cells. J. Biol. Chem. 257:9300-9304.

6. Boerner, P., T. L. Mason, and T. D. Fox. 1981. Synthesis and processing of ribosomal RNA in isolated yeast mitochondria. Nucleic Acids Res. 9:6379-6390.

7. Cantatore, P. and G. Attardi. 1980. Mapping of nascent light and heavy strand transcripts on the physical map of HeLa cell mitochondrial DNA. Nucleic Acids Res. 8:2605-2625.

8. Casey, J. and N. Davidson. 1977. Rates of formation and thermal stabilities of RNA:DNA and DNA:DNA duplexes at high concentrations of formamide. Nucleic Acids Res. 4:1539-1552.

9. Crews, S. and G. Attardi. 1980. The sequence of the small ribosomal RNA gene and the phenylalanine tRNA gene are joined end to end in human mitochondrial DNA. Cell 19:775784.

10. Crews, S., D. Ojala, J. Posakony, J. Nishiguchi, and G. Attardi. 1979. Nucleotide sequence of a region of human mitochondrial DNA containing the precisely identified origin of replication. Nature (London) 277:192-198.

11. Dubin, D. T., J. Montoya, K. D. Timko, and G. Attardi. 1982. Sequence analysis and precise mapping of the $3^{\prime}$ ends of HeLa cell mitochondrial ribosomal RNAs. J. Mol. Biol. 157:1-19.

12. Gaines, G., and G. Attardi. 1984. Intercalculating drugs and low temperature inhibit synthesis and processing of ribosomal RNA in isolated human mitochondria. J. Mol. Biol. 172:451-466.

13. Gelfand, R., and G. Attardi. 1981. Synthesis and turnover of mitochondrial ribonucleic acid in HeLa cells: the mature ribosomal and messenger ribonucleic acid species are metabolically unstable. Mol. Cell. Biol. 1:497-511.

14. Groot, G. S. P., N. van Harten-Loosbroek, G.-J. B. van Ommenn, and H. L. A. Pijst. 1981. RNA synthesis in isolated yeast mitochondria. Nucleic Acids Res. 9:6379-6390.

15. Hare, J. F., E. Ching, and G. Attardi. 1980. Isolation, subunit composition and site of synthesis of human cytochrome $\mathrm{c}$ oxidase. Biochemistry 19:2023-2030.

16. Harold, F. M. 1972. Conservation and transformation of energy by bacterial membranes. Bacteriol. Rev. 36:172-230.

17. Henderson, P. J. F. 1971. Ion transport by energy-conserving biological membranes. Annu. Rev. Microbiol. 25:393-428.

18. Hirsch, M., and J. Penman. 1973. Mitochondrial polyadenylic acid-containing RNA: localization and characterization. J. Mol. Biol. 80:379-391.

19. Montoya, J., T. Christianson, D. Levens, M. Rabinowitz, and G. Attardi. 1982. Identification of initiation sites for heavy strand and light strand transcription in human mitochondrial DNA. Proc. Natl. Acad. Sci. U.S.A. 79:7195-7199.

20. Montoya, J., G. L. Gaines, and G. Attardi. 1983. The pattern of transcription of the human mitochondrial rRNA genes reveal two overlapping transcription units. Cell 34:151-159.

21. Montoya, J., D. Ojala, and G. Attardi. 1981. Distinctive features of the $5^{\prime}$ terminal sequences of the human mitochondrial mRNAs. Nature (London) 290:465-470.

22. Newman, D., and N. Martin. 1982. Synthesis of RNA in isolated mitochondria from Saccharomyces cerevisiae. Plasmid 7:66-76.

23. Ojala, D., and G. Attardi. 1974. Expression of the mitochondrial genome in HeLa cells. XIX. Occurrence in mitochondria of polyadenylic acid sequences, "free" and covalently linked to mitochondrial DNA-coded RNA. J. Mol. Biol. 82:151-174.

24. Ojala, D., and G. Attardi. 1980. Fine mapping of the ribosomal RNA genes of HeLa cell mitochondrial DNA. J. Mol. Biol. 138:411-420.

25. Ojala, D., S. Crews, J. Montoya, R. Gelfand, and G. Attardi. 1981. A small polyadenylated RNA (7S RNA), containing a putative ribosome attachment site, maps near the origin of mitochondrial DNA replication. J. Mol. Biol. 150:303-314.

26. Ojala, D., C. Merkel, R. Gelfand, and G. Attardi. 1980. The tRNA genes punctuate the reading of genetic information in human mitochondrial DNA. Cell 22:393-403.

27. Ojala, D., J. Montoya, and G. Attardi. 1981 . The tRNA punctuation model of RNA processing in human mitochondria. Nature (London) 290:470-474.

28. Posakony, J. W., J. M. England, and G. Attardi. 1977. Mitochondrial growth and division during the cell cycle in HeLa cells. J. Cell Biol. 74:468-491.

29. Saris, N.-E., and K. E. O. Akerman. 1980. Uptake and release of bivalent cations in mitochondria. Curr. Top. Bioenerg. 10:103179.

30. Walberg, M. W., and D. A. Clayton. 1983. In vitro transcription of human mitochondrial DNA. J. Biol. Chem. 258:1268-1275. 